\title{
Relationship between ordinal position and academic achievement among adolescents: A study
}

\author{
Farzana Alim and A. A. Salsabeel Bano \\ Department of Home Science, Aligarh Muslim University, Aligarh, India
}

\begin{abstract}
Ordinal position refers to the actual order in which a child is born; that is first, second, third ... sixth, seventh and so on. Children of a family though sharing the same genetic pools from both of their parents and also raised in a similar environment attain different capabilities in their adult lives. There has been some research in the past to understand why such differences occur. However, these researches have either not considered academic achievement - which in the modern competitive world is often considered as one of the key criterion to judge one's total potential and capability - as one of their parameters of study or the final conclusions so drawn fail to clearly define the relationship between ordinal position and academic achievement. In this paper an attempt has been made to examine a relationship between the ordinal position and academic achievement. For this purpose, a sample of 50 children was selected which was limited to the young adolescents (age 13-16 years). The results do not reveal a clear relationship between the ordinal position and academic achievement; however, these results cannot be generalized because the study has been conducted on a small sample. Notwithstanding this, it is hoped that the results from this pilot study will help to broaden the research by also including other groups.
\end{abstract}

Keywords: birth order relationship, high achievers, low achievers

The journal is a publisher member of Publishers International Linking Association Inc. (PILA)-Crossref (USA). ( ) Institute of Research Advances : $\underline{\text { http://research-advances.org/index.php/IJEMS }}$ 


\section{Introduction}

In simple terms, ordinal position refers to the birth order a family member holds within the family such as: an only child, first-born, second-born, third-born and last-born etc. [1, 2]. However, research has proven that the birth order itself, on which the above definition of ordinal position is based, is actually quite a complex concept and there are many different theories and opinions about it [3]. Further, research in the past has shown that the birth order also has a significant role on how a child develops in a family. For example, it has been shown in the past that the first-borns are mostly responsible, high achievers and perfectionists whereas last-borns and only-child are usually the baby of the house and spoilt kids [4]. On the other hand, the middle-borns remain in a difficult position as they are younger to the older siblings and older to the younger siblings. Similarly, in a family, siblings differ in terms of intelligence, personality development and achievements. Many researchers believe that the birth order affects how a child develops and several researchers have tried to study relationships between birth order and psychological outcomes including mental health, intelligence, academic achievement, and personality [5]. The academic achievement could be directly linked to the number of years that a child gets to attend the school or maybe the total number of years of education. Researchers have proved that the number of years a child gets to attend the school and the total number of years of education are dependent upon the birth order. For example, a research was conducted by Black et al. [6] on a sample data from Norway in which it was observed that the children at the earlier birth position received larger number of years of education. A similar study was found by Herrera et al. [7] and Travis and Kohli [8]. However, none of these studies have been in the Indian context. In the Indian context, finding a relationship between birth order and academic achievement will be very interesting because in the Indian society, academic achievement is considered as an important criterion to judge one's total potentialities and capacities. The Indian society is becoming highly competitive for everybody and thus the young ones can not be left unaffected. For future success the Indian parents expect and wish that their children climb the ladder of performance to as high level of achievement as possible. In view of this, it has become imperative to study the relationship between ordinal position and academic achievement among adolescents in Indian context. In this study the following research questions were investigated.

1. Is there a significant relationship between ordinal position and academic achievement among adolescents?

2. Is there a significant relationship between ordinal position and academic achievement in adolescent boys?

The journal is a publisher member of Publishers International Linking Association Inc. (PILA)-Crossref (USA). ( Institute of Research Advances : http://research-advances.org/index.php/IJEMS 
3. Is there any significant relationship between ordinal position and academic achievement in adolescent girls?

\subsection{Objectives and Hypotheses}

The study was conducted to answer the all important question: whether the birth order was related to academic achievement? To answer this, following objectives were set out:

1. To find a relationship between ordinal position and academic achievement among adolescents.

2. To find a relationship between ordinal position and academic achievement in adolescent boys.

3. To find a relationship between ordinal position and academic achievement in adolescent girls.

To achieve the abovementioned set of objectives, the following hypotheses were framed:

1. There is a significant relationship between ordinal position and the academic achievement among adolescents.

2. There is a significant relationship between ordinal position and academic achievement in adolescent boys.

3. There is a significant relationship between ordinal position and academic achievement in adolescent girls.

The methodology presented in the following section, and the results obtained by using this methodology, demonstrate how the abovementioned objectives are met and whether the proposed hypotheses are accepted or rejected.

\section{Methodology}

The study was carried out in the schools of the Civil Lines area of Aligarh city (Uttar Pradesh, India). For the present study, both the descriptive and inferential statistics were used by the

The journal is a publisher member of Publishers International Linking Association Inc. (PILA)-Crossref (USA). ( ) Institute of Research Advances : $\underline{\text { http://research-advances.org/index.php/IJEMS }}$ 
investigator. The dependent variables were academic achievement and gender of adolescents and the independent variable was ordinal position for this study.

\subsection{Sample}

A sample of 50 adolescent students was collected by the convenience sampling method. All the sampled students were in the age group of young adolescents (13-16 years), with the mean age being 14.5 years. While collecting samples for the study, care was taken that both boys and girls equally represented the group so that the effect of gender on the results could be studied, however, as can be seen from Table 1, which shows the detailed breakdown of the samples, there were more girls in the group than boys. Preliminarily, the collected samples were categorized according to ordinal position as well: $30 \%$ were first-born, $46 \%$ were middle-born and $24 \%$ were last-born.

\subsection{Procedure}

The tool used for the collection of data for the study was a general background questionnaire which was distributed to the participants of the survey. The participants were then asked to respond to various questions and their responses were gathered and analysed by using simple statistical techniques. The questionnaire had straightforward questions in simple language so that the targeted group of young adolescents did not face any difficulty while answering them. The participants were asked about their ordinal position and marks obtained (in percentage) in their previous academic class. The participants provided their marks in CGPA and were converted in percentage. These marks were taken as precursors of the participant's academic achievement. Detailed results along with their analysis and interpretation are presented in the next section.

\section{Results, Analysis and Interpretation}

Table 2 shows the mean and the standard deviation (SD) of the percentage marks that were achieved by various participants of the survey. The mean percentage mark for the first-born was 71.82 with a SD of 13.46 , while the same for the middle- and last-born were 77.42 with an SD of 7.81 and 77.14 with an SD of 11.41, respectively. The same is shown in Tables 3 and 4 for the boys and girls group.

The bivariate associations between birth order and academic achievement were tested for statistical significance using single factor analysis of variance (ANOVA) test. To apply this test the following null hypotheses were framed:

The journal is a publisher member of Publishers International Linking Association Inc. (PILA)-Crossref (USA). ( Institute of Research Advances : http://research-advances.org/index.php/IJEMS 
- For the whole group, there exists no significant relationship between ordinal position and academic achievement among adolescents.

- For the boys group, there exists no significant relationship between ordinal position and academic achievement among adolescent boys.

- For the girls group, there exists no significant relationship between ordinal position and academic achievement among adolescent girls.

Also, the following were chosen as the source of variation of variance: variation between the groups of first-borns, middle-borns and last-borns and variation within each of these groups. The results after the application of the single factor ANOVA test are presented in Table 5. As can be clearly seen, F-ratio is less than F-critical for all the groups, therefore the abovementioned null hypotheses cannot be rejected and we can say the following: the academic achievement of adolescents (boys and girls) is independent of the ordinal position. Thus, statistically, the results show that there is no significant relationship between ordinal position and academic achievement among adolescents - or in other words, the birth order effects on academic achievement are non-existent. Further, as none of the differences between means are significant, there is no requirement for further testing, like carrying out a t- test.

\section{Conclusions}

A study was conducted to see the effect of ordinal position on academic achievement by collating results of a simple questionnaire-based survey. By conducting single point ANOVA test, it has been found that there exists no relationship between ordinal position and the academic achievement. However, given that the sample size was limited to 50 participants, the results from this study cannot be generalized. Hence, given the present data and particularistic sample, however, the information from this study was insufficient from which to draw such a strong conclusion - evidence at this point is inconclusive at best, because academic achievement was judged merely by considering the percentage marks converted from their CGPA that the participant received in his/her previous academic year. In reality, there can be several other factors that need to be considered for defining academic achievement and further studies will need to be conducted to concrete the results from this study.

The journal is a publisher member of Publishers International Linking Association Inc. (PILA)-Crossref (USA). (O) Institute of Research Advances : $\underline{\text { http://research-advances.org/index.php/IJEMS }}$ 


\section{References}

[1] Forer, L.K. (1976). The birth order factor: How your personality is influenced by your place in the family. New York, NY: D. McKay Company.

[2] Leman, K. (1998). The New Birth Order Book. Michigan: Baker Publishing Group.

[3] Mills, K.Y. and Mooney G.A. (2013). Methods of ranking birth order: The neglected issue in birth order research. The journal of individual psychology, 69(4), pp. 357-370.

[4] Sampson, E. and Hancock F. (1998). An examination of the relationship between ordinal position, personality \& conformity. Journal of Personality and Social Psychology, 5(4), 398407.

[5] Sulloway, F. J. (1996). Born to rebel: Birth order, family dynamics, and creative lives. New York, NY: Pantheon Books.

[6] Black, S.E., Devereux, P.J. and Salvanes, K.G. (2005). The more the merrier? The effect of family size and birth order on children's education. The Quarterly Journal of Economics, 669700 .

[7] Herrera, N.C., Zajonc, R.B., Wieczorkowska, G. and Cichomski, B. (2003). Beliefs about birth rank and their reflection in reality. Journal of Personality \& Social Psychology, 85(1), 142150.

[8] Travis, R. and Kohli, V. (1995). The birth order factor: Ordinal position, social strata, and educational achievement. Journal of Social Psychology, 135(4), 499-507.

[9] Klas, N. (2002). A literature review: a closer look at ordinal positioning within the family system. MSc. Thesis, University of Wisconsin-Stout.

The journal is a publisher member of Publishers International Linking Association Inc. (PILA)-Crossref (USA). (๑) Institute of Research Advances : http://research-advances.org/index.php/IJEMS 


\section{TABLES}

Table 1. Percentage-wise distribution of ordinal position

\begin{tabular}{|c|c|c|c|}
\hline \multirow{2}{*}{ Ordinal position } & \multicolumn{2}{|c|}{ Group of } & \multirow{2}{*}{ Total } \\
\cline { 2 - 3 } & Boys & Girls & \\
\hline First-born & 04 & 11 & 15 \\
\hline Middle-born & 11 & 12 & 23 \\
\hline Last-born & 05 & 07 & 12 \\
\hline Total & 20 & 30 & 50 \\
\hline
\end{tabular}

Table 2. Mean percentage marks of the whole group according to ordinal position

\begin{tabular}{|c|c|c|c|}
\hline Ordinal position & Count & Mean marks (in \%) & Standard Deviation \\
\hline First-born & 15 & 71.82 & 13.46 \\
\hline Middle-born & 23 & 77.42 & 7.81 \\
\hline Last-born & 12 & 77.14 & 11.41 \\
\hline
\end{tabular}

Table 3. Mean percentage marks of the boys group according to ordinal position

\begin{tabular}{|c|c|c|c|}
\hline Ordinal position & Count & Mean marks (in \%) & Standard Deviation \\
\hline First-born & 04 & 78.75 & 13.74 \\
\hline Middle-born & 11 & 70.63 & 10.11 \\
\hline Last-born & 05 & 68.20 & 7.66 \\
\hline
\end{tabular}

Table 4. Mean percentage marks of the girls group according to ordinal position

\begin{tabular}{|c|c|c|c|}
\hline Ordinal position & Count & Mean marks (in \%) & Standard Deviation \\
\hline First-born & 11 & 73.91 & 14.26 \\
\hline Middle-born & 12 & 76.50 & 6.80 \\
\hline Last-born & 7 & 77.85 & 14.10 \\
\hline
\end{tabular}

Table 5. Single factor ANOVA test on percentage marks for various groups

\begin{tabular}{|c|c|c|c|}
\hline \multirow{2}{*}{} & \multicolumn{3}{|c|}{ Group of } \\
\cline { 2 - 4 } & All & Boys & Girls \\
\hline F-ratio & 1.32 & 1.27 & 0.27 \\
\hline F-critical & 3.19 & 3.59 & 3.35 \\
\hline
\end{tabular}

The journal is a publisher member of Publishers International Linking Association Inc. (PILA)-Crossref (USA). (C) Institute of Research Advances : http://research-advances.org/index.php/IJEMS 